\title{
Linalool Induces Reactive Oxygen Species Mediated Apoptosis in Human Oral Squamous Carcinoma Cells
}

\author{
RAJANGAM PUSHPALATHA, GANAPATHY SINDHU ${ }^{\text {* }}$ \\ LAKSHMANAN VENNILA AND ANNAMALAI VIJAYALAKSHMI ${ }^{2}$ \\ RAMALINGAM \\ SHARMILA, \\ G. TAMIZHARASI, \\ Department of Biochemistry and Biotechnology, Faculty of Science, Annamalai University, Annamalai Nagar 608002, \\ ${ }^{1}$ Department of Biochemistry, Government Arts College (Autonomous), Kumbakonam 612002, ${ }^{2}$ Post Graduate \& Research \\ Department of Biochemistry, Rabiammal Ahamed Maideen College for Women, Tiruvarur 610001, Tamil Nadu, India
}

\section{Pushpalatha et al.: Linalool Induces Apoptosis in Human Oral Squamous Carcinoma Cells}

\begin{abstract}
Development of oral cancer is associated with excessive cell proliferation, deregulation in cellular differentiation, insufficient apoptosis and genomic instability. Linalool is a natural monoterpene, contained in edible plants, considered to have potent antioxidant nature. In this context, it should be necessitate in broadening the understanding of the anticancer potential of linalool in experimental oral cancer model, which could be beneficial in anticancer therapy. Hence, this study is intended to assess the anticancer quality of linalool in keratin-forming tumor cell line. 3-(4, 5-dimethylthiazolyl-2)-2, 5-diphenyltetrazolium bromide assay was conducted to find out the half maximal inhibitory concentration of linalool in keratinforming tumor cell line. Linalool induced the loss of cell viability or cell death by a clear dose and time dependent manner. The half maximal inhibitory concentration on keratin-forming tumor cell line cells is 13, 24 and $45 \mu \mathrm{M}$ for 24, 48 and $72 \mathrm{~h}$ respectively. Morphological changes, increased level of intracellular level of reactive oxygen species and loss of mitochondrial transmembrane potential of keratin-forming tumor cell line cells were evidently visualized on staining. Early growth 1 phase arrest in the cell cycle of keratin-forming tumor cell line cells was confirmed on dose and time dependent manner when compared with control during linalool treatment. Linalool treatment in various concentrations in vitro in keratinforming tumor cell line cells was able to reduce cell viability as compared to its counterparts. This study showed that linalool was a potent growth inhibitor of keratin-forming tumor cell line. In near future in vivo screening for its anticancer activity will be warranted and a linkage map will be developed between in vivo and in vitro studies.
\end{abstract}

Key words: Linalool, reactive oxygen species, in vitro study, apoptosis, cell cycle, keratin-forming tumor cell line cells, mitochondrial membrane potential

Cancer is the foremost health issue in many parts of the World ${ }^{[1]}$. It is characterized by out of control in cell proliferation and development leading to excessive propagation and metastasis. Carcinoma in squamous cells is the preponderance malignant epithelial neoplasm distressing the head and neck. It spreads principally by local extension and to some extent seldom by the lymphatics. The degree of tumor invasion based upon the anatomic site, the aggressive nature of tumor and host response factors. Developing countries including India have reported with $62 \%$ of global annual incidence of over 300000 cases. Severe alcohol consumption, use of tobacco in cigarettes, smokeless tobacco with betel nut chewing and Human Papilloma Virus (HPV) are the most dreadful risk factors for oral cancer ${ }^{[2]}$. More than $70 \%$ of the cases imply for diagnostic and treatment

*Address for correspondence E-mail: ganapathysindhu@gmail.com

September-October 2021 services are in difficult stages of the disease, ensuing in deprived survival with hiked mortality ${ }^{[3]}$. Early revealing and avoidance of oral premalignancy and cancer are thus quite important.

Need of the hour in the development of specific modulator which enhances antitumor activity and reduces adverse side effects of conventional antitumor agents. A reasonable number of purified constituents from medicinal plants exhibit beneficial therapeutic

This is an open access article distributed under the terms of the Creative
Commons Attribution-NonCommercial-ShareAlike 3.0 License, which
allows others to remix, tweak, and build upon the work non-commercially,
as long as the author is credited and the new creations are licensed under
the identical terms Accepted 06 September 2021 Revised 14 July 2021 Received 15 October 2019 Indian J Pharm Sci 2021;83(5):906-917 
potentials. Linalool is one among them used to restrict the abnormal growth of various human cancer cells by specifically inducing apoptotic cell death. Linalool is a natural monoterpene, occurs in edible plants, considered to have potent antioxidants. It is a chief volatile constituent of the essential oils of a number of aromatic plant species including Coriandrum sativum Linn, lavender (Lavandula officinalis) and sweet basil (Ocimum basilicum) ${ }^{[4]}$. Linalool containing essential oils possess ample of pharmacological properties, including anti-inflammatory, antimicrobial, cardioprotective, anti-aging, neuroprotective, antidiabetic, antiallergic, analgesic and local anesthetic activities, antihyperalgesic and antinociceptive and inhibited the enzymatic activities of some drug metabolizing enzymes ${ }^{[5-9]}$.

Cancer cell line derived from tumor tissue not only provide a fundamental platform to understand molecular biology of neoplasia, but also serve as a basis for the investigation of specific therapeutic strategies towards specific cancer types. The understanding of cell cycle and apoptosis helps to predict which molecules are effective in oral cancer treatment. Human oral cancer cell line, Keratin-forming tumor cell line $(\mathrm{KB})$ is the most commonly used oral cancer cell line in the in vitro analysis for anticancer drug screening. In vitro assay is more sensitive to test most anti-tumor agents. It is also less expensive and requires less test material and time. Though the anti-tumor activity against several human tumor cell lines by linalool has been shown, its molecular mechanisms inhibiting tumor cell growth are not fully understood. In this context, it should be necessitating in broadening the understanding of the anticancer prospective of linalool in experimental oral cancer model, which could be beneficial in anticancer therapy. Therefore, this study is designed to evaluate the anticancer effect of linalool in KB cell lines.

\section{MATERIALS AND METHODS}

Linalool was purchased from Sigma Aldrich chemicals, India. Fetal Bovine Serum (FBS) was purchased from Sigma USA. Dulbecco's Modified Eagle's Medium (DMEM), streptomycin, penicillin-G, phosphate buffered saline (PBS), 3-(4, 5-dimethylthiazolyl-2)-2, 5-diphenyltetrazolium bromide (MTT), 2'-7'dichlorofluorescin diacetate (DCFH-DA), Ethylene Diamine Tetra Acetic Acid (EDTA), Carboxymethylcellulose (CMC), Acridine orange (AO), Ethidium bromide (EB), Tris-Hcl Buffer, triton X-100, ethanol, sodium acetate, Dimethyl sulfoxide (DMSO), tween 20, were purchased from Hi Media Laboratories, Mumbai.

\section{Cell culture maintenance:}

Human oral carcinoma KB cells were obtained from National Centre for Cell Lines (NCCS), Pune, India. The cell lines were maintained in culture in DMEM supplement with $10 \%$ fetal calf serum, $100 \mathrm{U} / \mathrm{ml}$ of penicillin and $100 \mu \mathrm{g} / \mathrm{ml}$ of streptomycin. Cells were maintained in $5 \% \mathrm{CO}_{2}$ incubator at $37^{\circ}$ and the experiments were carried out after confluence stage was attained. The medium was replaced every $2 \mathrm{~d}$ and the maintenance was strictly followed in accordance with the standard methods.

\section{Cell viability assay:}

The cells were plated separately in 96 well plates at a concentration of $1 \times 10^{5}$ cells/well. After $24 \mathrm{~h}$, cells were washed twice with $100 \mu \mathrm{l}$ of serum-free medium and starved for an hour at $37^{\circ}$. After starvation, cells were incubated in a $\mathrm{CO}_{2}$ incubator at $37^{\circ}$ at various time periods $(24,48$ and $72 \mathrm{~h})$. At the end of the treatment period the medium was aspirated and serum free medium containing MTT $(0.5 \mathrm{mg} / \mathrm{ml})$ was added and incubated for $4 \mathrm{~h}$ at $37^{\circ}$ in a $\mathrm{CO}_{2}$ incubator. The MTT containing medium was then discarded and the cells were washed with PBS $(200 \mu 1)$. The crystals were then dissolved by adding $100 \mu \mathrm{l}$ of DMSO and this was mixed properly by pipetting up and down. Spectrophotometrical absorbance of the purple blue formazan dye was measured in a microplate reader at $570 \mathrm{~nm}$ (Biorad 680). The results are expressed at the percentage of stable cells with respect to the control. The half maximal inhibitory concentration $\left(\mathrm{IC}_{50}\right)$ values were calculated and the optimum doses were analyzed at different time period.

Inhibition of cell proliferation (\%)=Mean absorbance of the control-Mean absorbance of the sample/Mean absorbance of the control $\times 10$

The medium effective dose $\left(\mathrm{IC}_{50}\right)$ is the amount of samples able to inhibit cell proliferation by $50 \%$, which was calculated graphically for each well proliferation curve.

\section{Apoptosis assay:}

$\mathrm{KB}$ cells were seeded $\left(5 \times 10^{4}\right.$ cells $/$ well $)$ in a 6 well plate and incubated for $24 \mathrm{~h}$. After treatment with $\mathrm{IC}_{50}$ dose of linalool for 24, 48 and $72 \mathrm{~h}$, the cells were detached, washed by cold PBS and then stained with a mixture of $\mathrm{AO}\left(100 \mu \mathrm{g} \mathrm{ml}^{-1}\right)$ and $\mathrm{EB}\left(100 \mu \mathrm{g} \mathrm{ml}^{-1}\right)$ at room 
temperature for $5 \mathrm{~min}$. The stained cells were observed by a fluorescence microscope at 40x magnifications. At the end of treatment the cells were collected and washed three times with PBS. The plates were stained with acridine orange/ethidium bromide (AO/EB 1:1 ratio; $100 \mu \mathrm{g} / \mathrm{ml}$ ) for $5 \mathrm{~min}$ and examined immediately under fluorescent microscope 40x magnification. While AO is taken up by both viable and nonviable cells and emits green fluorescence if intercalated into double stranded nucleic acid (Deoxyribonucleic acid (DNA)) or red fluorescence if bound to single stranded nucleic acid (Ribonucleic acid (RNA)). EB is taken up only by nonviable cells and emits red fluorescence by intercalation into DNA

\section{Detection of apoptotic nuclei by 4',6-diamidino-2- phenylindole (DAPI) staining:}

$\mathrm{KB}$ cells were seeded onto a 12 well plate, $48 \mathrm{~h}$ before being treated with linalool. The cells were incubated for various range of time exposure 24,48 and $72 \mathrm{~h}$. The control cultures were treated with $0.1 \%$ DMSO. After incubation, cells were fixed with $3.7 \%$ formaldehyde for $15 \mathrm{~min}$, permeabilized with $0.1 \%$ Triton X-100 and stained with $1 \mathrm{mg} / \mathrm{ml}$ DAPI for $5 \mathrm{~min}$ at $37^{\circ}$. The cells were then washed with PBS and examined by fluorescence microscopy (Nickon Eclipse TS100).

\section{Measurement of Reactive Oxygen Species (ROS):}

Dichlorofluorescein (DCF) is oxidized by radicals such as hydroxyl, peroxyl, alkoxyl, nitrate and carbonate to a fluorescent molecule (excitation $530 \mathrm{~nm}$, emission $485 \mathrm{~nm}$ ). DCF is not oxidized by hydrogen peroxide or superoxide radical. Overnight grown cells were treated in 24 well plates $(45 \mu \mathrm{l} / \mathrm{ml})$ for $24 \mathrm{~h}$. After exposure, cells were washed by centrifugation and loaded with $20 \mu \mathrm{M}$ DCFH-DA in DMEM for $30 \mathrm{~min}$ at $37^{\circ}$. Thereafter, treated cells were washed with DMEM and fluorescent was recorded every $5 \mathrm{~min}$ in over $30 \mathrm{~min}$ (excitation $485 \mathrm{~nm}$, emission $535 \mathrm{~nm}$ ) using a spectrofluorimetry at $37^{\circ}$. ROS increase was calculated as mean slope per min and normalized to the unexposed control.

\section{Measurement of Mitochondrial Membrane Potential (MMP):}

The possible effect of linalool in disturbing MMP was evaluated using the lipophilic cationic fluorescent probe Rhodamine 123 (Rh-123) for mitochondria. The cells were incubated with vehicle alone or with linalool for various range of time exposure 24,48 and $72 \mathrm{~h}$. Rh123 was supplementary to attain a final concentration of $10 \mu \mathrm{g} / \mathrm{ml}$ and the $\mathrm{KB}$ cells were incubated for $30 \mathrm{~min}$ at $37^{\circ}$. Then the cells were swept away with PBS and observed under fluorescence microscope using blue filter.

\section{Cell cycle analysis:}

For flow cytometric analysis of cell cycle, KB cells at a density of $1.5 \times 10^{5}$ cells $/ \mathrm{ml}$ were treated with both DMSO alone (vehicle control) and linalool at 24 and $48 \mathrm{~h}$. All adhering and floating cells were harvested and washed with cold PBS, ice-cold $70 \%$ ethanol was fixed, the cells and incubated at $-20^{\circ}$ overnight. The cells were incubated with $500 \mu$ of hypotonic Propidium iodide (PI) solution $(10 \mathrm{ml}$ sodium citrate, $0.25 \mathrm{mg}$ of PI and $0.4 \mathrm{mg}$ of Ribonuclease (RNase) and $0.3 \mu \mathrm{l}$ of tween 20 for $10 \mathrm{ml}$ ) at $37^{\circ}$ for $30 \mathrm{~min}$ staining in the dark at $4^{\circ}$. Flow cytometry analysis was performed in the Central Instrumentation Scientific Laboratory (CISL), Annamalai University using flow cytometer (BD FACS Aria III) equipped with a $633 \mathrm{~nm}, 488 \mathrm{~nm}$ and $375 \mathrm{~nm}$ air-cooled Argon laser collecting at least 10000 events. The DNA profile indicated the relative abundance of the cell population in sub growth 1 phase $\left(\mathrm{G}_{1}\right)$, resting phase $\left(\mathrm{G}_{0}\right) / \mathrm{G}_{1}$, synthesis phase (S) and growth 2 phase $\left(\mathrm{G}_{2}\right) /$ mitosis $(\mathrm{M})$ phases.

\section{Statistical analysis:}

The data are expressed as mean \pm standard deviation (SD) statistical comparisons were performed by oneway Analysis of Variance (ANOVA), followed by Duncan's Multiple Range Test (DMRT) using Statistical Package for the Social Sciences (SPSS) version 17.0 for windows. The results were considered statistically significant values $\mathrm{p}<0.05$.

\section{RESULTS AND DISCUSSION}

Linalool induced time and dose-dependent cytotoxicity. The MTT cell viability assay is the primary step for screening anticancer effect of test compound in vitro. Cells were treated with different concentrations of linalool (in concentration range from 5 to $80 \mu \mathrm{M} /$ $\mathrm{ml})$ at different duration ranges $(24,48$ or $72 \mathrm{~h})$ to clarify the role in the time of exposure. Fig. 1 shows the dose and time-dependent activity of linalool for all duration ranges. We chose different incubation times to determine the most effective one. While the inhibition of cell viability was obtained after linalool treatment only for the highest concentrations $80 \mu \mathrm{M} / \mathrm{ml}$, prolonged treatments $(24,48$ and $72 \mathrm{~h})$ caused significant inhibition of viability for all concentrations. The cell proliferation at $72 \mathrm{~h}$ treatment resulted in an increase in $\mathrm{IC}_{50}$ 
$(13 \mu \mathrm{M})$ values (inhibitory dose at inhibited cell growth by $50 \%$ ). A significant time dependent inhibition of cell proliferation was not obtained when only exposing the cells to the lower concentrations after $72 \mathrm{~h}$ and this did not strengthen along with the longer time of exposure. Low concentrations can kill cells immediately after treatment, but after longer time of exposure, cells may recover and they can stimulate some proliferative effects in surviving cells (fig. 1-fig. 3).

DCFH-DA can pass through the cytomembrane and is oxidized by ROS. The increased fluorescence signal of the product DCF indicates the accumulation of peroxides and superoxides, important elements in apoptosis. Linalool induced ROS generation in $\mathrm{KB}$ cells. Excessive production of ROS may lead to oxidative stress, loss of cell function and ultimately apoptosis. In order to demonstrate the role that ROS play in linalool-induced cell death, intracellular ROS generation was examined by using an oxidant sensitive fluorescent probe, DCFH-DA. As shown in fig. 4, the DCF signal was observed in $\mathrm{KB}$ cells treatment with short term exposure $(24 \mathrm{~h})$ of linalool $(43 \mu \mathrm{M})$ and in control cells. An elevation of intracellular fluorescence intensity has been shown to occur within $20 \mathrm{~min}$ after

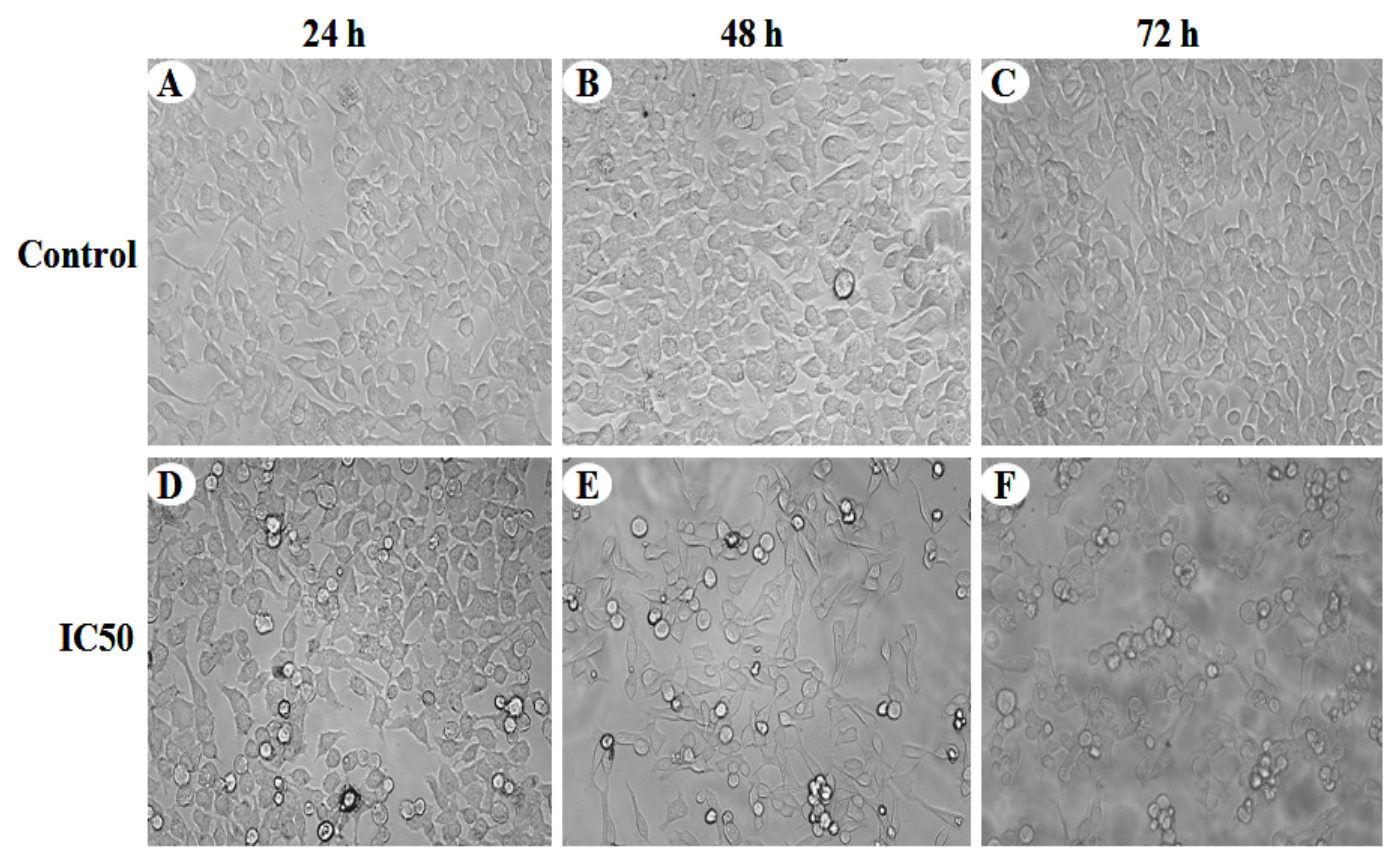

Fig. 1: Morphological changes in control and linalool treated $\mathrm{KB}$ cells. The images captured by light microscope showing A, B and C intact morphology of $K B$ cells and $D, E$ and $F$ shows the $I_{50}: 43,30$ and $13 \mu \mathrm{M}$ at various time periods of 24,48 and $72 \mathrm{~h}$ respectively

\section{Oral cancer cells}

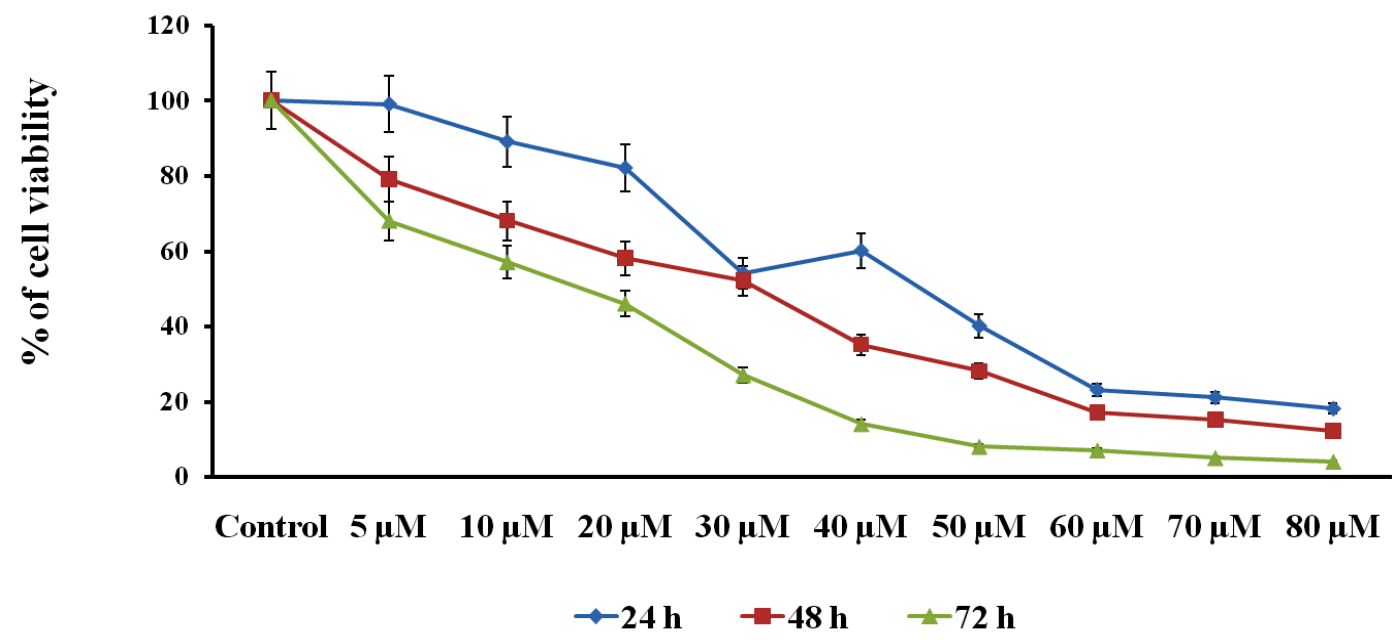

Fig. 2: Effect of linalool on the growth of KB cells by MTT assay. It shows linalool induced cytotoxicity in cellosaurus cell line (HOC) $\mathrm{KB}$ cells at various concentrations $(5,10,20,25,30,40,50,60,70$ and $80 \mu \mathrm{M})$ for 24,48 and $72 \mathrm{~h}$. Values were presented as mean $\pm \mathrm{SD}$ of three independent experiments 


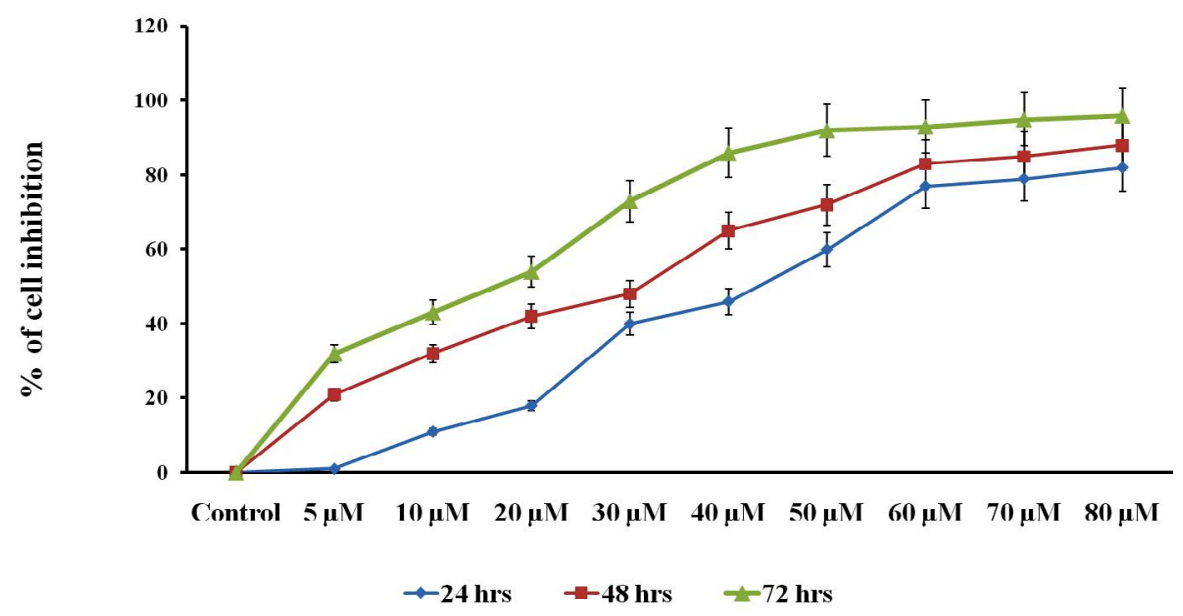

Fig. 3: Effect of linalool on the inhibition of KB cells growth by MTT assay. It shows HOC KB cells treated with control and linalool at various concentrations $(5,10,20,25,30,40,50,60,70$ and $80 \mu \mathrm{M})$ for 24,48 and $72 \mathrm{~h}$. Linalool inhibits the growth of $\mathrm{KB}$ cells in a time and dose dependent manner. Values were presented as mean \pm SD of three independent experiments
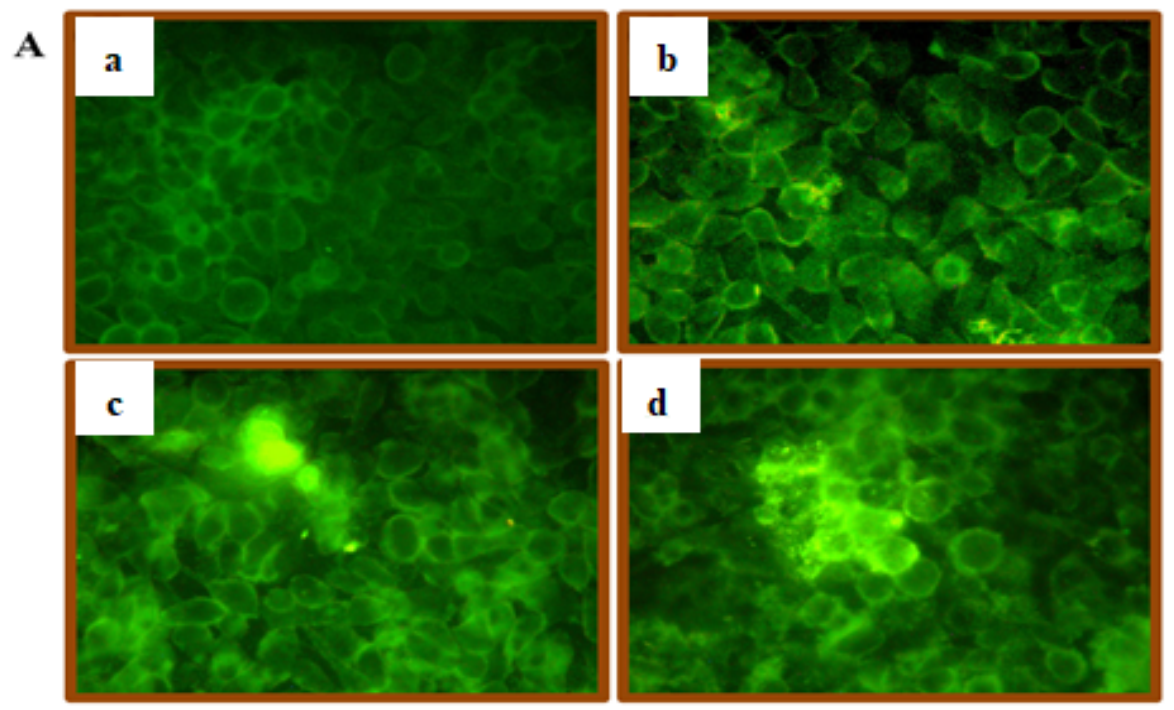

B

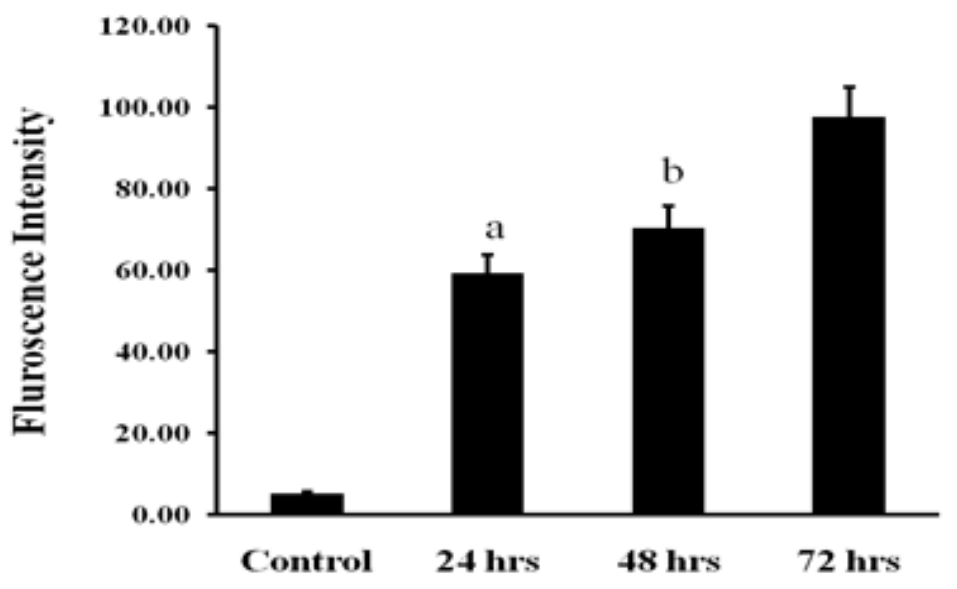

Treatments

Fig. 4: ROS measurement in control and linalool treated KB cells. (A) KB cells were treated with linalool (IC $\mathrm{C}_{50}: 43,30$ and $\left.13 \mu \mathrm{M} / \mathrm{ml}\right)$ at various time periods for $(24,48$ and $72 \mathrm{~h})$, stained with DCFH-DA dye. Then the digital images were captured by Fluorescence microscope, (a) Control (green florescence); (b) KB cells exposed with linalool for $24 \mathrm{~h}$; (c) KB cells exposed with linalool for 48 h; (d) KB cells exposed with linalool for 72 h; (a and b) depicted weak background DCF florescence; (c and d) depicted bright DCF florescence in KB cells treated with linalool in time dependent manner; (B) Intracellular ROS measurement by spectrofluorimeter. Results shows a time dependent increase in ROS production during linalool treatment cells as shown by increased \% DCF staining ratio. Values were presented as mean \pm SD of three experiments in each group one way ANOVA followed by DMRT. (a\&b)indicate statistically different from control: ${ }^{\mathrm{a}} \mathrm{p}<\mathbf{0 . 0 5}$; and ${ }^{\mathrm{b}} \mathbf{p}<0.001$ 
cell incubation with linalool ( $\mathrm{IC}_{50}: 43,30$ and $\left.13 \mu \mathrm{M}\right)$ at various time periods 24,48 and $72 \mathrm{~h}$ respectively when increase in time of incubation, the oxidized form of cells were also increased time dependently.

It is well known that ROS participate in apoptosis by inducing loss of MMP. This study examined the effect of linalool on MMP in KB cells. The mitochondrial transmembrane potential was investigated with the fluorescent probe $\mathrm{Rh}-123$. Rh-123 is a cationic fluorescent dye that exhibits potential-dependent accumulation and formation of red fluorescent aggregates in mitochondria that have high MMP. In contrast, the Rh-123 exists as a monomer that produces green fluorescence in the cytoplasm and mitochondria that have low MMP.

When cells were incubated with linalool $\left(\mathrm{IC}_{50}: 43\right.$, 30 and $13 \mu \mathrm{M}$ ) for 24,48 and $72 \mathrm{~h}$, linalool induced a marked decrease in red fluorescence intensity compared to those in control cells (fig. 5). Present data indicated that a remarkable drop in MMP occurred in cells exposed to linalool $43 \mu \mathrm{M}$ ( $\mathrm{IC}_{50}$ value) for $24 \mathrm{~h}$ (fig. 5). Based on the above data, linalool-induced KB cell death was dependent on ROS production and MMP disturbance. Table 1 presents in vitro cytotoxic activities of the linalool, which were expressed by $\mathrm{IC}_{50}$ values. The $\mathrm{IC}_{50}$ value used here was confirmed from cytotoxicity assay. The results showed that maximum effect has been exhibited by linalool $\left(\mathrm{IC}_{50}: 30\right.$ and $13 \mu \mathrm{M}$ ) after 48 and $72 \mathrm{~h}$, indicating that time of exposure is most important factor to measure antiproliferative effects.
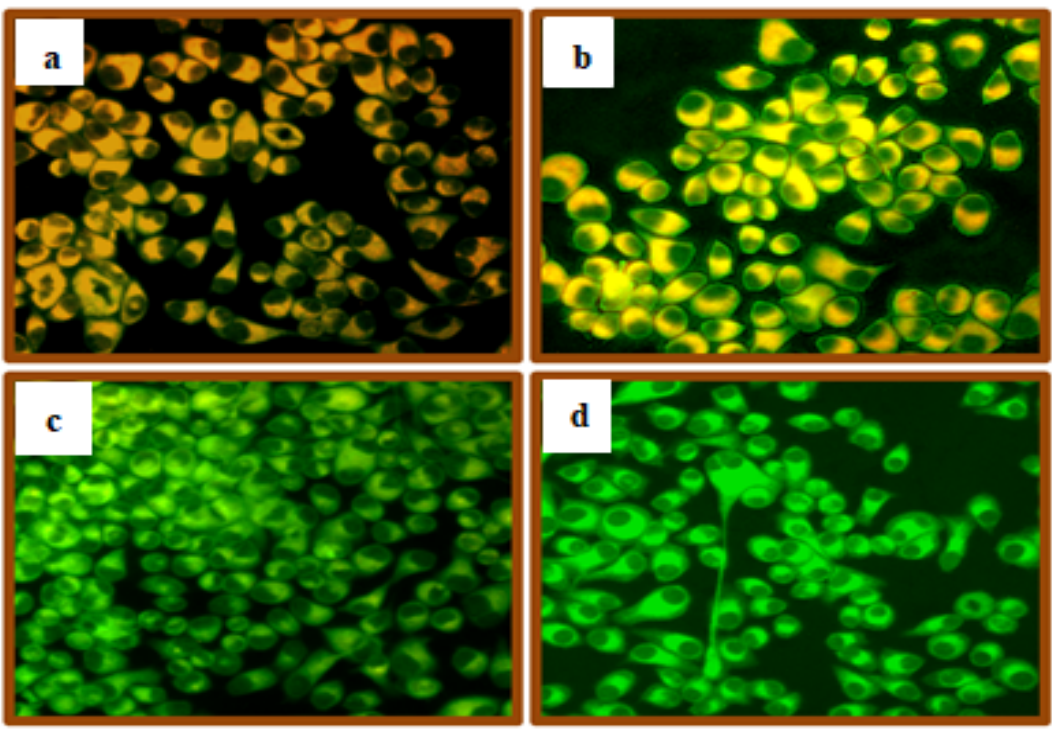

B

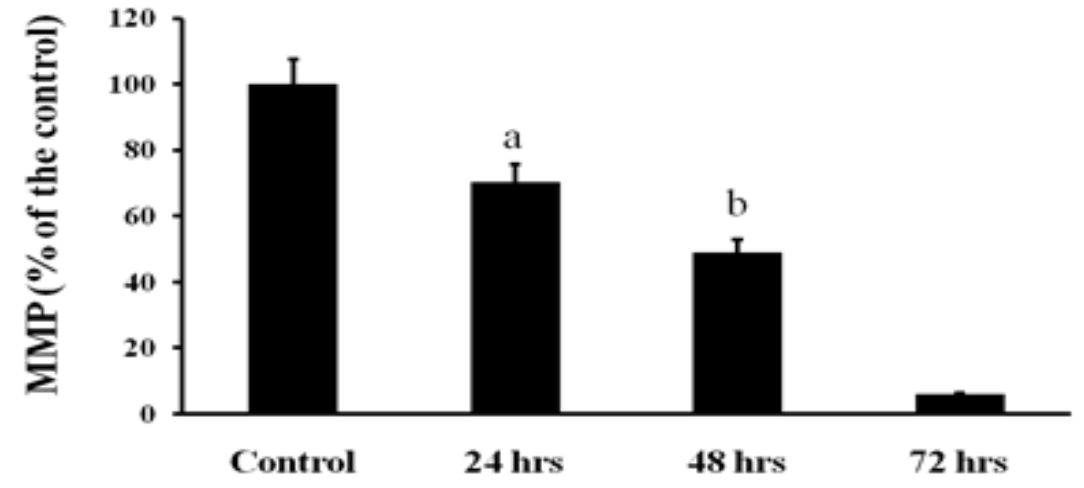

Treatments

Fig. 5: Quantification of MMP in control and linalool treated KB cells. (A) KB cells were treated with linalool for (IC ( $_{50}: 43,30$ and 13 $\mu \mathrm{M} / \mathrm{ml}$ ) different time periods at 24, 48 and $72 \mathrm{~h}$, stained with $\mathrm{Rh}-123$ and the results showed mitochondrial depolarization patterns of KB cells. The gradual decrease of red/green fluorescence indicates a decreased MMP in a time dependent manner were analyzed by fluorescent microscope. The photomicrograph shows (a) Control (high Rh-accumulation); (b) KB cells exposed with linalool for $24 \mathrm{~h}$ (moderate Rh-accumulation); (c) KB cells exposed with linalool for $48 \mathrm{~h}$ (low Rh-accumulation); (d) KB cells exposed with linalool for $72 \mathrm{~h}$ (No Rh-accumulation). (B) Quantification of MMP in spectrofluorimeter. Values are given as mean \pm SD of six experiments in each concentration, one way ANOVA followed by DMRT. ${ }^{(a \& b)}$ indicate statistically different from control: ${ }^{\text {a }} \mathbf{p}<0.05$; ${ }^{\mathrm{b}} \mathbf{p}<\mathbf{0 . 1}$ 
To confirm the type of cell death induced by the linalool $\left(\mathrm{IC}_{50}: 43,30\right.$ and $\left.13 \mu \mathrm{M}\right)$ for 24,48 and $72 \mathrm{~h}$ in $\mathrm{KB}$ cells, the morphological changes after dual staining with $\mathrm{AO}$ and EB were investigated. These dyes emit different shades of fluorescence and possess a different ability to penetrate cells. AO penetrates into living cells, emitting

TABLE 1: THE CYTOTOXIC EFFECT OF LINALOOL ON KB CELLS

\begin{tabular}{lcc}
\hline Time & $\begin{array}{c}50 \% \text { Inhibition dose } \\
\left(\text { IC }_{50}: \mu \mathrm{M}\right)\end{array}$ & $\begin{array}{c}\text { Mean } \pm \text { standard error } \\
\text { of mean (SEM) }\end{array}$ \\
\hline $24 \mathrm{~h}$ & $43 \mu \mathrm{M}$ & $0.018 \pm 0.001^{\mathrm{a}}$ \\
$48 \mathrm{~h}$ & $30 \mu \mathrm{M}$ & $0.092 \pm 0.029^{\mathrm{a}}$ \\
$72 \mathrm{~h}$ & $13 \mu \mathrm{M}$ & $0.105 \pm 0.007^{\mathrm{b}}$ \\
\hline
\end{tabular}

The values are presented as mean $\pm \mathrm{SD}$ of three determinations and indicated by ${ }^{(a \& b)}$ showed a significant difference ${ }^{a} p<0.05,{ }^{b} p<0.1$ respectively relative to the relevant control green fluorescence after intercalation into DNA. The second dye, EB emits red fluorescence in the cells with altered cell membrane integrity. Morphological features of apoptosis such as chromatin condensation, nuclear fragmentation, alterations in the size and the shape of cells, as revealed by fluorescence microscopic analysis, were observed predominantly after linalool treatment at $\mathrm{IC}_{50}: 43,30$ and $13 \mu \mathrm{M}$ for 24,48 and $72 \mathrm{~h}$. The maximum increase in the number of apoptotic cells was observed in $\mathrm{IC}_{50}-13 \mu \mathrm{M}$ of linalool in long term treatment $72 \mathrm{~h}$, which was significantly higher compared to the control. As shown in fig. 6 the different time exposure of the linalool treatment also induced the necrosis.

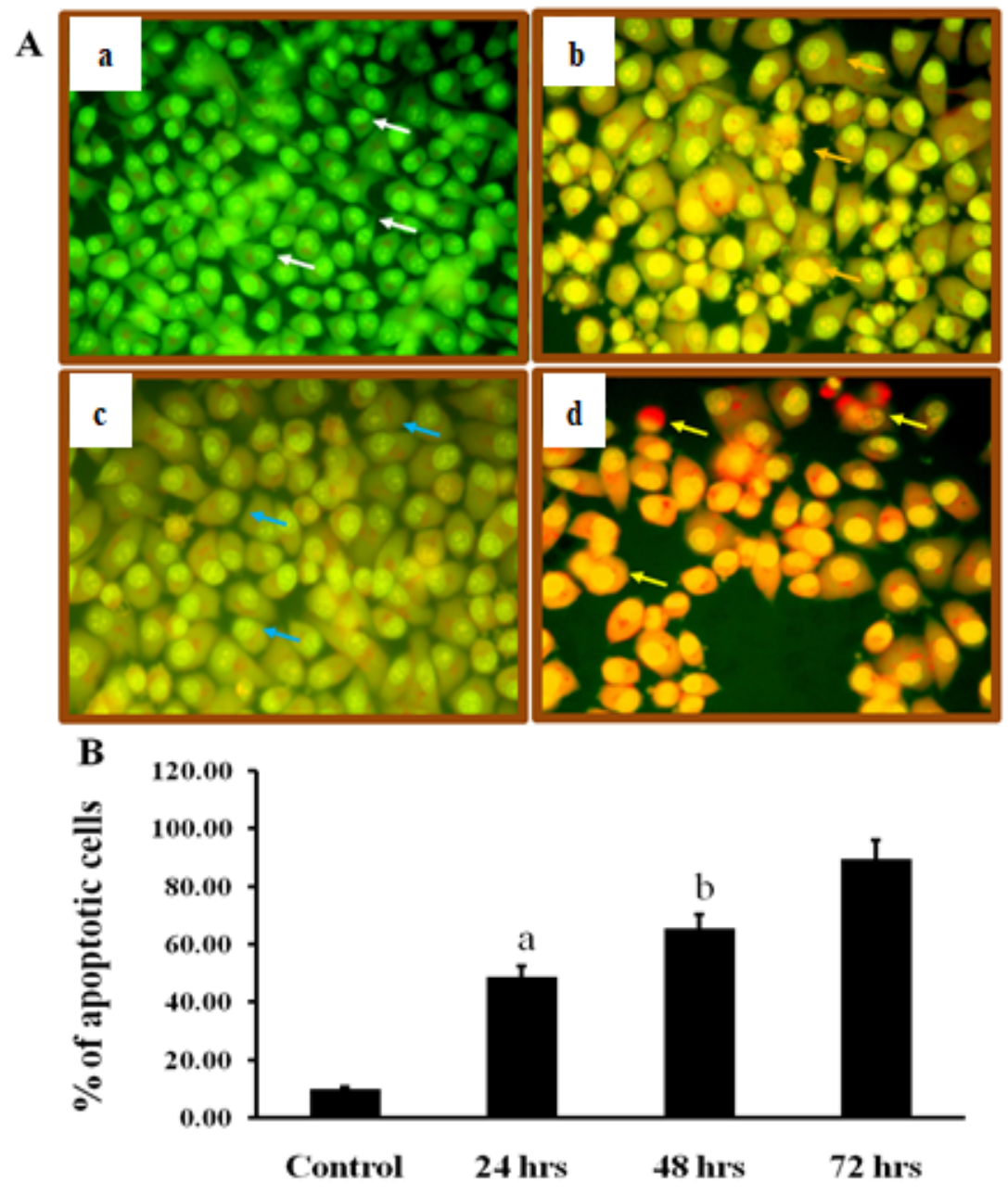

Treatments

Fig. 6: Apoptosis measurement in control and linalool treated $\mathrm{KB}$ cells. (A) KB cells treated with vehicle and linalool (IC $\mathrm{I}_{50}$ : 43,30 and $13 \mu \mathrm{M} / \mathrm{ml}$ ) for various time periods at 24,48 and $72 \mathrm{~h}$, stained with dual dye EB/AO and then analyzed by fluorescence microscopy (Nickon Eclipse TS-100); (a) control KB cells (green florescence); (b, c and d) representative images of linalool treatment for 24, 48 and $78 \mathrm{~h}$ respectively. White arrow indicates live cells; Orange arrow indicates apoptotic bodies; Blue arrow indicates apoptotic cells; Yellow arrow indicates necrotic cells. (B) Percentage of apoptotic cells were calculated by scoring apoptotic and viable cells. The values are given as mean \pm SD of six experiments in each group one-way ANOVA followed by DMRT. ${ }^{(a \&)}$ indicate statistically different from control: ${ }^{\mathrm{a}} \mathrm{p}<\mathbf{0 . 0 5},{ }^{\mathrm{b}} \mathrm{p}<\mathbf{0 . 0 1}$ 
To further investigate whether the induction of cell death by linalool was a typical apoptosis in KB cells, the analysis of nuclear morphology were performed. Treatment of KB cells with linalool resulted in nuclear morphology alterations as evidenced by the DAPI staining, a DNA binding dye. The nuclei feature of control cells was round; whereas irregular nuclei were seen in cells at 24, 48 and $72 \mathrm{~h}$ after treatment with linalool (fig. 7). In DAPI staining, it is obvious that the morphological features are characteristically different from established features of apoptosis or necrosis. Linalool at 24, 48 and $72 \mathrm{~h}$ period exposed $\mathrm{KB}$ cells shows with apoptotic features and a few necrotic cells.

Effects of linalool on cell cycle distribution (fig. 8A) in $\mathrm{KB}$ cells were studied after exposure to linalool $\left(\mathrm{IC}_{50}: 43\right.$ and $\left.30 \mu \mathrm{M}\right)$ for 24 and $48 \mathrm{~h}$, respectively. The control cells showed a typical distribution of cell cycle phases. Linalool had a significant impact on the cell cycle. In KB cells, the linalool-induced inhibition of proliferation may be through $\mathrm{G}_{0} / \mathrm{G}_{1}$ arrest. We observed a reduction in the percentage of linalool treated KB cells in the $\mathrm{S}$ phase $(0.1 \%$ and $0.5 \%)$ and in $\mathrm{G}_{2} / \mathrm{M}$ phase $(0.4 \%$ and $0.5 \%)$ when compared to the control $\mathrm{KB}$ cells at $24 \mathrm{~h}$ and $48 \mathrm{~h}$ along the cell cycle. Although there was a consistent trend toward accumulation of linalool-treated $\mathrm{KB}$ cells in the $\mathrm{G}_{1}$ phase $(28.79 \%$ and $20.9 \%$ ) of the cell cycle at 24 and $48 \mathrm{~h}$ respectively. This effect was statistically significant $\mathrm{p} \leq 0.2$ in linalool $\left(\mathrm{IC}_{50}: 43 \mu \mathrm{M}\right)$ at short term $(24 \mathrm{~h})$ treated KB cells and $\mathrm{p} \leq 0.01$ in linalool $\left(\mathrm{IC}_{50}: 30 \mu \mathrm{M}\right)$ treated for long term $(48 \mathrm{~h})$. The additive effect of $\mathrm{G}_{1}$ phase accumulation likely accounts for the observed decrease in $\mathrm{S}$ and $\mathrm{G}_{2}$ phase accumulation, followed by increase in the population of cells in sub $G_{1}$ phase in a time dependent manner. This increase in sub $G_{1}$ was $G_{1} / S$ transition. These results indicate that linalool regulates the cell
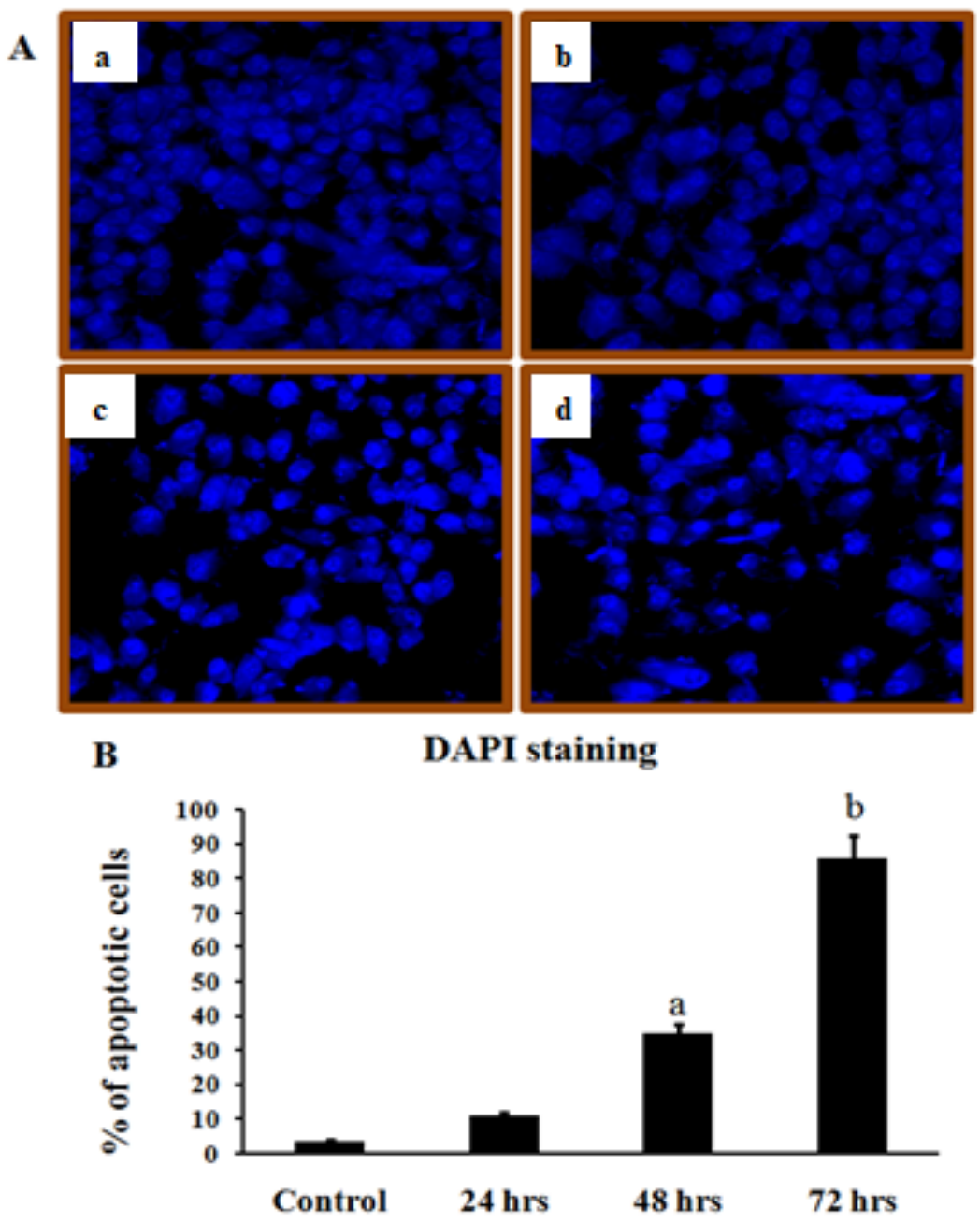

Fig. 7: Apoptosis measurement in control and linalool treated KB cells by DAPI staining. (A) KB cells were exposed with linalool $\left(\mathrm{IC}_{50}: 43,30\right.$ and $13 \mu \mathrm{M} / \mathrm{ml}$ ) for 24,48 and $72 \mathrm{~h}$, fixed with $4 \%$ paraformaldehyde and nuclear staining was performed using DAPI. The KB cells stained by DAPI were observed under a fluorescence microscope; (B) Effect of linalool on percentage of cells displaying apoptotic morphology. Apoptotic cells were counted and data shown in the graphs are expressed as mean \pm SD of triplicate experiments. ${ }^{\mathrm{a}} \mathbf{p}<\mathbf{0 . 0 5},{ }^{\mathrm{b}} \mathbf{p}<\mathbf{0 . 0 1}$ compared with the control group 


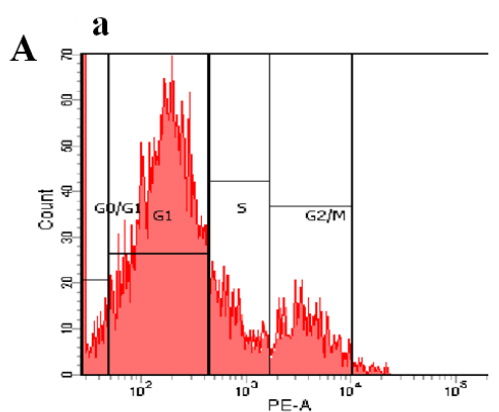

B
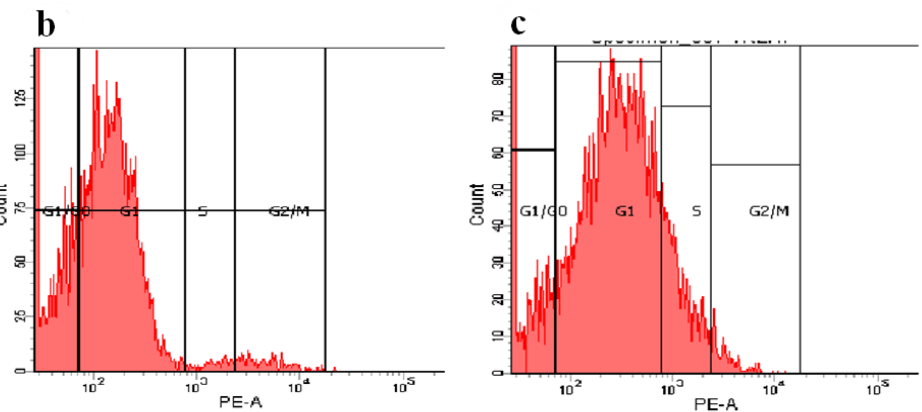

- Control $\approx 24$ hrs $\square 48$ hrs

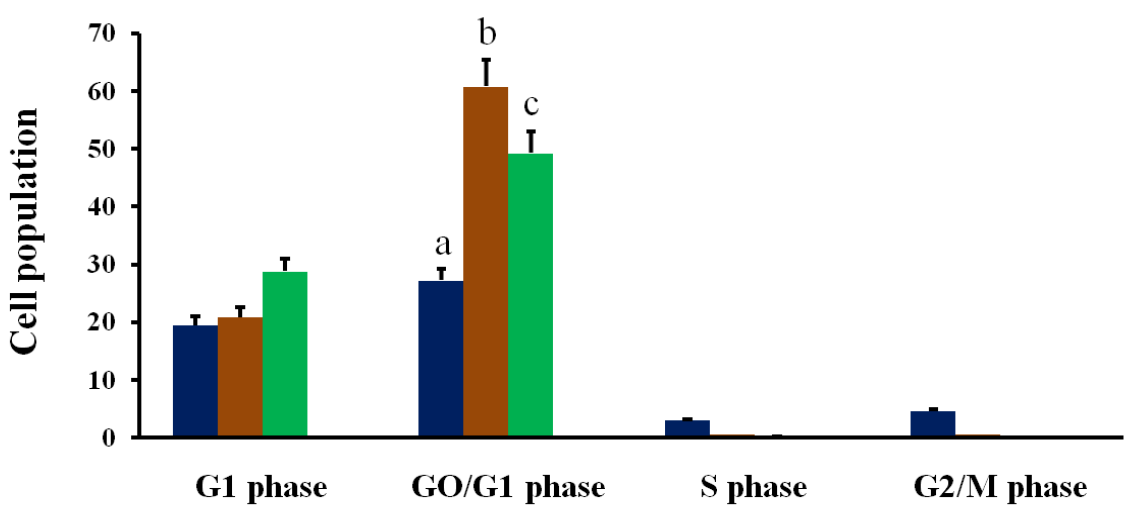

Cell cycle distribution

Fig. 8: Cell cycle distributions. (A) Cell cycle distributions of (a) Control (0.5\% DMSO treated) and (b and c) linalool (IC ( $_{50}: 43$ and $30 \mu \mathrm{M} / \mathrm{ml}$ ) treated $\mathrm{KB}$ cells at various time periods for $24 \mathrm{~h}$ and $48 \mathrm{~h}$ were determined using PI staining by flow cytometry and quantification. (B) Histograms showing the number of the channel (vertical axis) against DNA content (horizontal axis). Linalool caused a dose dependent $G_{1}$ phase accumulation and a corresponding decrease in the percentage of cells entering $S$ and $G_{2} / M$ phase. The values are presented as mean \pm SD of three determinations and indicated by $a, b$, $c$ showed a significant difference ${ }^{a} p<0.05$, ${ }^{\mathrm{b}} \mathbf{p}<0.01,{ }^{\mathrm{c}} \mathbf{p}<0.02$ respectively relative to the relevant control

cycle at $\mathrm{G}_{1} / \mathrm{S}$ phase in $\mathrm{KB}$ cells thereby affects their proliferation pattern.

Prevention and therapy is undeniable, the prudent maneuver towards the ultimate target of cancer controlling. The global level increase in the use of herbal measures and active ingredients isolated from medicinal plants have delivered the pharmaceutical industry with important sources of lead compounds. Furthermore, over a 100 new products are in clinical development, particularly as anticancer agents. Several dietary phytochemicals are an alternative due to their various degrees of antiproliferative and immunostimulatory effects on various types of human cancer. A recent study revealed that suppression of oral cancer by induction of cell cycle arrest and apoptosis using Juniperus communis extract ${ }^{[10]}$. Therefore process of identification of new phytochemicals with chemopreventive and therapeutic efficacy starts with the analysis of their effect on experimental cancer cell line models. Our current study shows that linalool exerts its cytotoxic effect in oral human cancer cell line, through a disturbance in cell cycle events, leading to cell death by apoptosis.

The MTT assay showed that linalool reduced the viability of the human oral cancer cell line $\mathrm{KB}$ in a dose and time dependent manner. Thus results indicate that linalool induced antiproliferative and/or cytotoxic effects of these cells. A few studies have reported previously that linalool exhibited good inhibitory effects against breast, colorectal and liver cancer cell[5,11]. Jabir et al. used the cytotoxicity assay to demonstrate the selective toxicity of linalool in cancer cells and induced apoptosis by activating caspase- 8 , the $\mathrm{p} 53$ protein in human ovary cancer cell line (SKOV-3) cells through extrinsic and intrinsic pathways ${ }^{[12]}$. It has been showed that linalool exerted antiproliferative activity against certain solid tumor cells, such as adenocarcinoma cells and human liver cancer cell line (HepG2). Alterations on KB cell viability were confirmed by phase contrast microscopy and flow cytometry. The linalool treated cells presented modification in cell morphology (fig. 1). In addition, the analysis using MTT confirmed 
the cytotoxicity and inhibition rate of linalool treated cells (fig. 1 and fig. 2). According to previous report, morphological alterations such as rounding and cell shrinkage are consistent with apoptotic cell death ${ }^{[13]}$. Moreover, given that linalool induces cell cycle arrest in $\mathrm{KB}$ cells, it could potentiate the cytotoxicity nature of cell cycle disrupting chemotherapeutics.

Apoptosis is a dynamic and physiological mode of cell death subjected to complex regulatory process, which is an important aspect to impede tumourigenesis. In this way, new strategies capable of inducing the apoptotic process in cancer cells are welcoming, modulating the sensitivity of tumor and normal cells to antitumor agents, via regulatory mechanism of apoptosis ${ }^{[14]} . \mathrm{KB}$ cells were analyzed in the presence of AO/EB staining so as to corroborate that apoptosis has been induced by linalool. The induction of apoptosis induced by early and late apoptotic morphological changes observed in $\mathrm{KB}$ cells was confirmed by dual staining which has been used to discuss living cells were in early and late stage of apoptosis. Cytological examination of linalool treated cells showed morphological characteristics consistent with apoptotic cell death (fig. 1). Other research groups have demonstrated that linalool induced apoptosis, growth arrest and differentiation in a variety of human leukemia cells but spared normal hematopoietic cells ${ }^{[15]}$. Mechanisms of cell death other than apoptosis (autophagic cell death, necroptosis, ferroptosis, etc.) were also mediated by linalool to exhibit its antitumor action $^{[16]}$. Gong et al. verified by morphological analysis that linalool inhibits the viability of Jurkat cells via inducing the apoptosis of leukemia cells ${ }^{[17]}$. Linalool treatment exhibited fragmentation of chromatin, bleb formation on the cell surface, cytoplasmic shrinkage, loss of cell-to-cell contact and a reduction in their density, which is representative apoptotic features. Mitochondria associated oxidative stress has been shown to play critical role in apoptotic cell death. Loss of MMP is an important event for induction of apoptotic cell death in human oral cancer cells. In this study it has been observed that significant alteration in MMP of linalool treated KB cell. Thus, there would be a correlation in linalool induced oxidative stress, a decrease in MMP and induction of apoptotic cell death in KB cells. Further the present results demonstrated that the ROS generation was significantly increased when the KB cells pretreated with linalool.

ROS were involved in cell growth inhibition and mitochondrial depolarization. Linalool increased ROS production and MMP depolarization ${ }^{[18]}$. To investigate the mechanism of anti-tumorigenic potential of linalool, we studied its effect on KB cells in terms of oxidative stress. It has been reported that modulation of ROS levels is a therapeutic strategy to selectively destruct cancer cells ${ }^{[19]}$. Excess levels of ROS in the cells can readily induce cell cycle arrest and apoptosis. Recent studies have showed utility of agents that increase cellular ROS levels may kill cancer cells effectively ${ }^{[20]}$. In our present study, generation of ROS was found to be higher in KB cells treated with linalool than untreated control KB cells in a time and dose dependent manner. Thus, proving that one of the mechanisms by which linalool killed KB cells is by elevating intracellular ROS. Oxidative stress was measured in $\mathrm{KB}$ cells in vitro to explore the involvement of oxidative stress in the observed reduction in viability of cancer cells. In addition, the preventive role of linalool on mitochondrial complex I and II, the electron transport followed by mitochondrial rearrangements and apoptosis in HepG2 cells were revealed ${ }^{[21]}$. Thus, the difference in the redox, metabolic and mitochondrial states between the cancer and normal organ tissues might be responsible for linalool's selective oxidative stress induction and selective cytotoxic to cancer cells. Results obtained from this study clearly demonstrated significant anticancer activity of linalool is mainly by increasing ROS production.

The flow cytometric method was employed to further test the linalool influence on the cell cycle events after treating linalool to KB cell. Fig. 8A and fig. 8B showed that linalool caused a $G_{1}$ phase accumulation. This observation is considered to be a hallmark of apoptotic cell death, as during apoptosis, chromosomal DNA is cleaved by a caspase activated deoxyribonuclease (DNase) to facilitate phagocytosis ${ }^{[22]}$. Recently it has been suggested that linalool could induce $\mathrm{G}_{0} / \mathrm{G}_{1}$ arrest and apoptosis in leukemia cells and in cervical cancer cells and significantly increased sub $\mathrm{G}_{1}$ phase and more cells were collected in $G_{1}$ phase lead to apoptosis ${ }^{[23]}$. Linalool was reported to induce $\mathrm{G}_{1}$ phase arrest in several types of cancer, such as oral cancer ${ }^{[24]}$, leukemia and hepatocellular carcinoma. In addition linalool blocked the transition through the $\mathrm{G}_{1}$ checkpoint to inhibit cancer growth in $22 \mathrm{Rv} 1$ prostate cancer cell ${ }^{[25]}$. Profound studies showed linalool had cytostatic antiproliferative effects against cancer cells by causing $\mathrm{G}_{0} / \mathrm{G}_{1}$ or $\mathrm{G}_{2} / \mathrm{M}$ cell growth arrest accompanied by a strong diminution of $\mathrm{S}$ phase cells. Our results suggested that linalool could induce apoptosis and $\mathrm{G}_{0} / \mathrm{G}_{1}$ arrest in $\mathrm{KB}$ cells at short and long term exposure of linalool. At $\mathrm{IC}_{50}$ $(30 \mu \mathrm{M})$ linalool presented the sub $\mathrm{G}_{1}$ peaks for $24 \mathrm{~h}$ 
and $48 \mathrm{~h}$ respectively as well as $\mathrm{S}$ and $\mathrm{G}_{2} / \mathrm{M}$ phase were reduced ultimately. Accordingly these results showed that linalool can effectively suspend the cell cycle of $\mathrm{KB}$ cells in phase $G_{1}$ and subsequently present sub $G_{1}$ phase early which symbolize the occurrence of suspended cell cycle. It was reported that treatment with linalool significantly increased the sub $G_{1}$ phase and there were more cells concentrated in the $\mathrm{G}_{1}$ phase. Particularly, linalool induces apoptosis in human leukemia cells without affecting normal hematopoietic cell growth ${ }^{[15]}$. Linalool become ligands in nuclear receptors thereby regulate expression of various genes and ameliorate conditions related to this disease ${ }^{[26]}$.

Earlier studies revealed that linalool treatment in sarcoma cancer cell line (S-180) cells reduced the cell viability, induced apoptosis and also increased number of cells in the sub $G_{0}$ phase in the sarcoma tissues by cells analysis, which demonstrated significant anticancer activity of the linalool. Further they were providing one of the mechanisms by which linalool killed KB cells were by elevating intracellular $\operatorname{ROS}^{[27]}$. In a pre-treatment experiment linalool has suppressed t-butyl hydroperoxide induced DNA damage in human hepatoma HepG2 and human lymphoid neural crest (NC) cells ${ }^{[6]}$. During linalool treatment the level of DNA strand breaks were higher, which may reflect faster excision of oxidized bases. In recent study, it showed that linalool effectively protects human cells against genotoxic effect of the ROS-inducing agent, without any adverse effects at nanomolar concentrations ${ }^{[28,29]}$.

An early study showed that natural small molecule monoterpene linalool possessed strong activity against histiocytic lymphoma cells U937 ( $\left.\mathrm{IC}_{50}: 3.51 \mathrm{~g} / \mathrm{ml}\right)$ and Burkitt lymphoma cells P3HR1 $\left(\mathrm{IC}_{50}: 4.21 \mathrm{~g} / \mathrm{ml}\right)^{[30]}$. Moreover, several recent studies reported that linalool could reverse doxorubicin resistance in human breast adenocarcinoma cells $\mathrm{s}^{[5]}$, displayed antiproliferative activity against some solid tumor cells, such as amelanotic melanoma and renal cell adenocarcinoma ${ }^{[31]}$, HepG2 and Michigan Cancer Foundation-7 (MCF7) cells ${ }^{[11,21]}$ as well as against a variety of leukemia cells ${ }^{[15]}$. Linalool managed all oxidation system parameters including reduced Glutathione (GSH), Superoxide dismutase (SOD), Catalase (CAT), Malondialdehyde (MDA), Nicotinamide Adenine Dinucleotide Phosphate (NADPH) and particularly the Nuclear Erythroid 2-related factor 2 (Nrf2) mediated pathway markers and potentiated the cytotoxic effect of cisplatin when investigated on Henrietta Lacks (HeLa) and Human prostatic carcinoma cell line $(\mathrm{PC}-3)^{[32]}$.
Linalool induced apoptosis of human colon cancer cells via cancer specific oxidative stress, which was detectable as an Electron Spin Resonance (ESR) signal by Kenichi et al. ${ }^{[33]}$.

Here we have analyzed that linalool was able to induce growth inhibition and apoptosis in human oral cancer cells KB. All of the results, obtained and presented here, illustrate that linalool is capable of inducing apoptotic cell death in KB cells. Further it was confirmed by measuring intracellular ROS, MMP, apoptosis and cell cycle progression. This study corroborated with earlier literatures that linalool was a potent growth inhibitor of KB cells. However the mechanism of linalool inhibits the growth of tumor cells remains to be fully elucidated. In near future in vivo screening for its anticancer activity will be warranted and a linkage map will be developed between in vivo and in vitro studies.

\section{Conflicts of interest:}

The authors declared no conflict of interest.

\section{REFERENCES}

1. Sivapriyadharshini S, Padma PR. Kaempferol exerts a differential effect on KB oral carcinoma. Int J Pharm Bio Sci 2016;7(3):1244-52.

2. Varshitha A. Prevalence of oral cancer in India. J Pharm Sci Res 2015;7(10):845-8.

3. Gillenwater A, Papadimitrakopoulou V, Richards-Kortum R. Oral premalignancy: new methods of detection and treatment. Curr Oncol Rep 2006;8(2):146-54.

4. Deepa B, Venkatraman Anuradha C. Effects of linalool on inflammation, matrix accumulation and podocyte loss in kidney of streptozotocin-induced diabetic rats. Toxicol Mech Methods 2013;23(4):223-34.

5. Ravizza R, Gariboldi MB, Molteni R, Monti E. Linalool, a plant-derived monoterpene alcohol, reverses doxorubicin resistance in human breast adenocarcinoma cells. Oncol Rep 2008;20(3):625-30.

6. Mitic-Culafic D, Zegura B, Nikolic B, Vukovic-Gacic B, Knezevic-Vukcevic J, Filipic M. Protective effect of linalool, myrcene and eucalyptol against t-butyl hydroperoxide induced genotoxicity in bacteria and cultured human cells. Food Chem Toxicol 2009;47(1):260-6.

7. Hussain J, Ullah R, ur Rehman N, Khan AL, Muhammad $\mathrm{Z}$, Hussain FU, et al. Endogenous transitional metal and proximate analysis of selected medicinal plants from Pakistan. J Med Plant Res 2010;4(3):267-70.

8. Miyashita M, Sadzuka Y. Effect of linalool as a component of Humulus lupulus on doxorubicin-induced antitumor activity. Food Chem Toxicol 2013;53:174-9.

9. Katsuyama M, Matsuno K, Yabe-Nishimura C. Physiological roles of NOX/NADPH oxidase, the superoxide-generating enzyme. J Clin Biochem Nutr 2011;50(1):9-22.

10. Lee CC, Hsiao CY, Lee SC, Huang XF, Chang KF, Lee MS, et al. Suppression of oral cancer by induction of cell cycle arrest and apoptosis using Juniperus communis extract. Biosci Rep 2020;40(9):BSR20202083. 
11. Paik SY, Koh KH, Beak SM, Paek SH, Kim JA. The essential oils from Zanthoxylum schinifolium pericarp induce apoptosis of HepG2 human hepatoma cells through increased production of reactive oxygen species. Biol Pharm Bull 2005;28(5):802-7.

12. Jabir M, Sahib UI, Taqi Z, Taha A, Sulaiman G, Albukhaty S, et al. Linalool-loaded glutathione-modified gold nanoparticles conjugated with CALNN peptide as apoptosis inducer and $\mathrm{NF}-\mathrm{KB}$ translocation inhibitor in SKOV-3 cell line. Int $\mathrm{J}$ Nanomedicine 2020;15:9025-47.

13. Vijayalakshmi A, Sindhu G. Umbelliferone arrest cell cycle at $\mathrm{G}_{0} / \mathrm{G}_{1}$ phase and induces apoptosis in human oral carcinoma (KB) cells possibly via oxidative DNA damage. Biomed Pharmacother 2017;92:661-71.

14. Thamizharasi G, Sindhu G. D-carvone inhibits growth, migration, cell cycle at $\mathrm{G}_{0} / \mathrm{G}_{1}$ phase and induces apoptosis in A431 cells by disrupting mitochondrial membrane potential. Int J Res Pharm Sci 2018;9(4):1465-75.

15. Gu Y, Ting Z, Qiu X, Zhang X, Gan X, Fang Y, et al. Linalool preferentially induces robust apoptosis of a variety of leukemia cells via upregulating p53 and cyclin-dependent kinase inhibitors. Toxicology 2010;268(1-2):19-24.

16. Zhao Y, Cheng X, Wang G, Liao Y, Qing C. Linalool inhibits $22 \mathrm{Rv} 1$ prostate cancer cell proliferation and induces apoptosis. Oncol Lett 2020;20(6):1.

17. Gong X, Wang B, Yan L, Lu X, Zhao X. Linalool inhibits the growth of human $\mathrm{T}$ cell acute lymphoblastic leukemia cells with involvement of the MAPK signaling pathway. Oncol Lett 2020;20(5): 1 .

18. Rodenak-Kladniew B, Castro MA, Crespo R, Galle M, de Bravo MG. Anti-cancer mechanisms of linalool and 1, 8-cineole in non-small cell lung cancer A549 cells. Heliyon 2020;6(12):e05639.

19. Kong Q, Beel JA, Lillehei KO. A threshold concept for cancer therapy. Med Hypotheses 2000;55(1):29-35.

20. Pelicano H, Feng L, Zhou Y, Carew JS, Hileman EO, Plunkett $\mathrm{W}$, et al. Inhibition of mitochondrial respiration: a novel strategy to enhance drug-induced apoptosis in human leukemia cells by a reactive oxygen species-mediated mechanism. J Biol Chem 2003;278(39):37832-9.

21. Usta J, Kreydiyyeh S, Knio K, Barnabe P, Bou-Moughlabay Y, Dagher S. Linalool decreases HepG2 viability by inhibiting mitochondrial complexes I and II, increasing reactive oxygen species and decreasing ATP and GSH levels. Chem Biol Interact 2009;180(1):39-46.

22. Darzynkiewicz Z, Li X, Gong J. Assays of cell viability: discrimination of cells dying by apoptosis. Methods Cell Biol 1994;41:15-38.

23. Chang MY, Shieh DE, Chen CC, Yeh CS, Dong HP. Linalool induces cell cycle arrest and apoptosis in leukemia cells and cervical cancer cells through CDKIs. Int J Mol Sci 2015;16(12):28169-79.

24. Pan W, Zhang G. Linalool monoterpene exerts potent antitumor effects in OECM 1 human oral cancer cells by inducing sub-G1 cell cycle arrest, loss of mitochondrial membrane potential and inhibition of PI3K/AKT biochemical pathway. J BUON 2019;24:323-8.

25. Zhao Y, Cheng X, Wang G, Liao Y, Qing C. Linalool inhibits 22Rv1 prostate cancer cell proliferation and induces apoptosis. Oncol Lett 2020;20(6):1.

26. Goto T, Takahashi N, Hirai S, Kawada T. Various terpenoids derived from herbal and dietary plants function as PPAR modulators and regulate carbohydrate and lipid metabolism. PPAR Res 2010;2010:1-9.

27. Jana S, Patra K, Sarkar S, Jana J, Mukherjee G, Bhattacharjee $\mathrm{S}$, et al. Antitumorigenic potential of linalool is accompanied by modulation of oxidative stress: An in vivo study in sarcoma-180 solid tumor model. Nutr Cancer 2014;66(5):83548.

28. Chang MY, Shen YL. Linalool exhibits cytotoxic effects by activating antitumor immunity. Molecules 2014;19(5):6694706.

29. Gunaseelan S, Balupillai A, Govindasamy K, Ramasamy $\mathrm{K}$, Muthusamy G, Shanmugam M, et al. Linalool prevents oxidative stress activated protein kinases in single UVBexposed human skin cells. PLoS One 2017;12(5):e0176699.

30. Chiang LC, Chiang W, Chang MY, Ng LT, Lin CC. Antileukemic activity of selected natural products in Taiwan. Am J Chin Med 2003;31(1):37-46.

31. Loizzo MR, Tundis R, Menichini F, Saab AM, Statti GA, Menichini F. Antiproliferative effects of essential oils and their major constituents in human renal adenocarcinoma and amelanotic melanoma cells. Cell Prolif 2008;41(6):1002-12.

32. Mohamed ME, Abduldaium YS, Younis NS. Ameliorative effect of linalool in cisplatin-induced nephrotoxicity: the role of $\mathrm{HMGB} 1 / \mathrm{TLR} 4 / \mathrm{NF}-\kappa \mathrm{B}$ and $\mathrm{Nrf} 2 / \mathrm{HO} 1$ pathways. Biomolecules 2020;10(11):1488.

33. Iwasaki K, Zheng YW, Murata S, Ito H, Nakayama K, Kurokawa $\mathrm{T}$, et al. Anticancer effect of linalool via cancerspecific hydroxyl radical generation in human colon cancer. World J Gastroenterol 2016;22(44):9765-74. 